\title{
CUSTOMER RELATIONSHIP MANAGEMENT PRACTICES OF INDIAN PUBLIC AND PRIVATE SECTOR BANKS: AN EXPLORATORY STUDY
}

\author{
Lalitha P S \\ Research Scholar \\ Department of Management Studies \\ Sri Venkateswara University, Tirupati, India \\ E-mail: lalithaparendur@gmail.com \\ Dr. Kiran Kumar Paidipati \\ Assistant Professor \\ Department of Statistics, Lady Shri Ram College for Women, \\ University of Delhi, New Delhi, India \\ E-mail: kirankumar.paidipati@1sr.du.ac.in

\section{Dr. Arvind Kumar \\ Professor \& Dean} \\ Atal Bihari Vajpayee School of Management and Entrepreneurship \\ Jawaharlal Nehru University, New Delhi, India \\ E-mail: kumararvind@mail.jnu.ac.in
}

\begin{abstract}
The contemporary study focused on the impact of CRM parameters to identify the influencing factors towards customer satisfaction and customer loyalty. A sample of 1200 respondents chosen from public sector (SBI and of Andhra bank) and private sector banks (ICICI and HDFC) using multi-stage random sampling technique through a structured questionnaire. The study employed various statistical tools such as Percentage Analysis for demographical information, bank variables, and the CRM parameters. Mean Ranks for ranking the items and Reliability Analysis applied for obtaining reliable variables in constructing the CRM parameters. Exploratory Factor Analysis (EFA) was performed to identify highly influenced factors of CRM practices to improve level of satisfaction and loyalty in public and private banks. The explored results enlighten directions to the banking sector to provide some operational implications such as proactive involvement from personnel, and customized outreach in engaging customers to reduce the negative word-of-mouth (WOM) and increase the productivity of banks positively. These significant CRM strategies will reduce the attrition rate and improves customer retention in future.
\end{abstract}

Keywords: Customer Experience, Banking Sector, CRM Parameters, Exploratory Factor Analysis, Customer Retention.

JEL Classification Codes: G210, G410, O180, D100.

\section{INTRODUCTION}

$\mathrm{CRM}$ is an acronym generally stands for customer relationship management while others mean it as customer relationship marketing too. In managerial emphasis, CRM is a discipline or an approach to acquire and develop suitable practices in maintaining profitable customer relationships. Customer is the most important asset to banks. The concept of CRM as a strategy reflects the banks to process in 
optimizing revenues, profitability and to gain the customer loyalty. Nowadays, banks are continually looking for ways to achieve a competitive advantage to customer expectation intensifies for quality and service. Consequently, CRM practices playing vital role in improving the customer's experience to maximize the profit and increase the business connections. Retaining the old customer is far cheaper than acquiring a new customer. Key issue for many banking organizations is customer retention often referred to as churn. Hence, there is a significant need in employing more CRM practices in banking system that would be helpful to maintain customer retention and help them manage customer defection (churn) rates and to enhance performance in reducing the attrition rate.

During the COVID-19 times, the banking sector has recorded its highest ever profits of Rs. $1,02,252$ crores in FY21, a year when the economy was battered by the pandemic. This is a significant turnaround compared to a net loss of nearly Rs. 5,000 crore for the industry in FY19. HDFC Bank contributed Rs. 31,116 crores accounted for 30\%, SBI accounted for another 20\% at Rs. 20,410 crores. The third-highest was ICICI Bank, which earned Rs. 16,192 crores, more than double what it earned in the previous year. Private Banks also gained market share as public sector banks (PSBs) went slow in lending as per the reports of RBI.

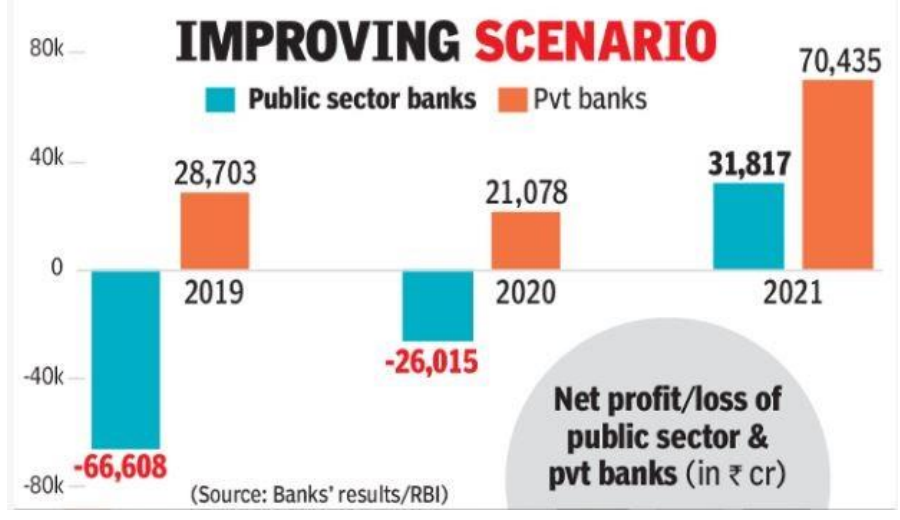

Figure 1. Net Profit/Loss of Public and Private Sector banks ${ }^{18}$

Banks want to strengthen customer experience by successful digital transformation and takes the customer insights with the new digital changes offered by banks like UPIs, BHIM, Google Pay, PhonePe, Paytm, and other money wallets. It is difficult to reach and meet every segment of customers, as usually banks target the maximum customer expectations and satisfaction levels. According to Amitabh Kant (NITI Aayog CEO) mentioned about phenomenal Unified Payment Interface (UPI) recorded 2.3 billion transactions through value worth 4.3 trillion in Jan 2021 on a Year -On-Year (YOY) basis jumped $76.5 \%$. To reach one billion transactions, UPI took 3 years times previously, the next billion will reach less than a year in the subsequent financial years.

In recent digital transformation drive postulates some positive benefits in terms of communication, Word of Mouth (WOM), sharing customer experience, and other valuable insights. CRM practices can help to monitor the feedbacks in terms of ratings and reviews, opinion from users' point of view and better implementing strategies in forthcoming days.
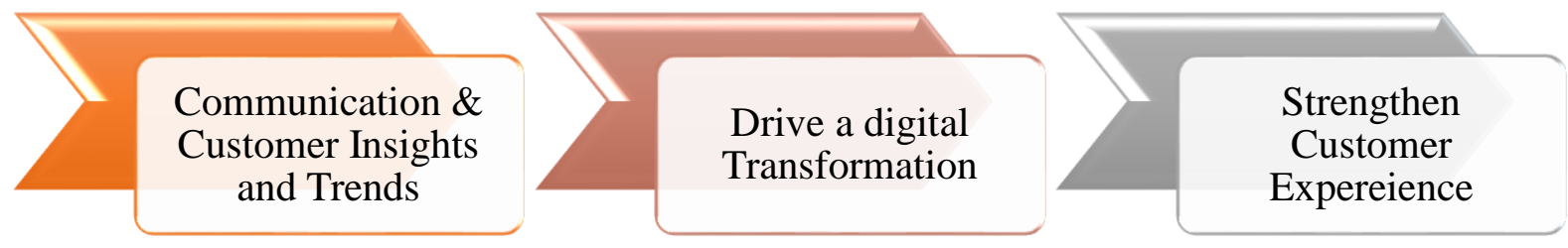

Figure 2. Importance of CRM 


\section{REVIEW OF LITERATURE}

Several studies explored CRM practices in banking sector which focused on diverse strategies to enhance the customer services. Starting from the specified study, loyalty was an attitude-based phenomenon influenced by customer relationship management initiatives affinity programs (Mark et al., 2003). The authors focused on customer service results in a positive customer attitude (Kirmaci, 2012). The study assessed the quality of service provide by private sector banks which dominate public sector banks in terms of customer service and providing awareness (Singh, 2013). Another study examined customers with various personal attributes, found differ in their expectations and perceptions in terms of quality, technological innovations usage. It initiates significant impact on technological relationship and their perceptions of CRM parameters to customer demographics (Law et al., 2013). The researchers observed the mediating role of customer trust among social identity and customer loyalty. Also, recognized the momentous influence of relationship marketing to influence positive customers so as it increased the identity, reputation, image on customer trust which affects customer loyalty (Nguyen et al., 2013).

The authors investigated positive relationship between CRM practices and customer loyalty in banking sector (Anabila \& Awunyo, 2013). The study described about services provided by private sector banks such as positive customer attitude helps to correct fulfilment of customer expectations, and positive perception of staff towards customer services improve the better CRM practices (Vugec et al., 2017). Another explored the implementation of CRM model, IDIC (Identify, Develop, Interact and Customization) was adopted in Nigerian banks to enhance customer retention (Karahan \& Kuzu, 2014). According to study identified that bank personnel get expertise technically in rendering services to the users, which setbacks appropriate strategies to banks efficiency (Khan et al., 2017).

Further an exploratory study focused on customer perception and customer orientation in the banking sector and suggested that inferred technology acts as a customer relation paradigm in engaging the customers (Dubey \& Sangle, 2019). Another study examined the success factors of CRM which includes customer information, system support, quality of service in turn results customer trust and retention towards banks financial performance (Al-Dmour et al., 2019). The influence of technological advancements in banks reduces customer retention (Bankole et al., 2020). The analytical CRM practices like online marketing services for effective communication channels made banks to become more customer - centric (Devendran, 2020). Finally, the researchers investigated the practical implications of deep learning technologies and their applications includes virtual service assistant, smart image processing, face recognition, personalized marketing, audio-video processing, user authorization, cybersecurity will save as the one-stop repository for banks and protects the assets, prevents losses from frauds. It aims to provide quality service to satisfy customers and reduce customer churn detections (Hassani et al., 2020).

Overall, the studies discussed on CRM parameters such as satisfaction, loyalty and retention etc., and effective practices to reduce the churn rates. There is a need of keen understanding about the customer behavior towards satisfaction and being loyal in banking sector. Several studies suggested certain improvements to be added in CRM practices to maintain the customer retention and reduce attrition. Our study will be another feather and mostly focused to study in-depth understanding of customer behavior in implementing CRM practices in the banking sector in India.

\section{RESEARCH METHODOLOGY}

The study envisioned in exploring significant CRM parameters in Indian public and private banking sector. The study considered rural and urban areas of one of the districts of India to understand the consumer behaviour towards implementing the CRM practices. The study designed in collecting 1200 samples with a structured questionnaire from three revenue divisions in Chittoor district, Andhra Pradesh, India using multi-stage sampling technique. The customers were selected from Public (SBI \& Andhra Bank) and Private (ICICI \& HDFC) sector banks of 600 customers each. 


\section{Statistical Tools used for Data Analysis}

Statistical tools such as Descriptive Statistics, Percentage Analysis, Reliability, Mean Ranks to understand demographical information among customers with different bank sectors, to check the reliability of CRM parameters and to rank the CRM parameters. Chi-square test is employed for finding the association between demographical information and CRM parameters, Factor Analysis is a dimension reduction technique used for knowing combined influence of CRM parameters in banking sector. The obtained results are properly concluded at various significance levels.

Table 1. Frequency Distribution for Demographic Variables with Type of Banking Sector

\begin{tabular}{|c|c|c|c|c|c|c|c|}
\hline \multirow{2}{*}{$\begin{array}{l}\text { S. } \\
\text { No. }\end{array}$} & \multirow{2}{*}{$\begin{array}{l}\text { Demographic } \\
\text { Variables }\end{array}$} & \multirow[t]{2}{*}{ Attributes } & \multicolumn{2}{|c|}{$\begin{array}{c}\text { Public Sector } \\
\text { Bank }\end{array}$} & \multicolumn{2}{|c|}{$\begin{array}{c}\text { Private Sector } \\
\text { Bank }\end{array}$} & \multirow{2}{*}{$\begin{array}{c}\text { Test - } \\
\text { Statistic }\end{array}$} \\
\hline & & & $\mathbf{N}$ & $\%$ & $\mathbf{N}$ & $\%$ & \\
\hline \multirow[b]{2}{*}{1} & \multirow[b]{2}{*}{ Gender } & Male & 385 & $64.2 \%$ & 424 & $70.7 \%$ & \multirow{2}{*}{$\begin{array}{l}\chi^{2}=5.770 \\
\text { and } \\
p=0.016(\mathrm{~S})\end{array}$} \\
\hline & & Female & 215 & $35.8 \%$ & 176 & $29.3 \%$ & \\
\hline \multirow{4}{*}{2} & \multirow{4}{*}{ Age } & ow 25 years & 102 & $17.0 \%$ & 163 & $27.2 \%$ & \multirow{4}{*}{$\begin{array}{l}\chi^{2}=22.561 \\
\text { and } \\
p=0.000(S)\end{array}$} \\
\hline & & $25-40$ years & 244 & $40.7 \%$ & 213 & $35.5 \%$ & \\
\hline & & $41-55$ years & 145 & $24.2 \%$ & 106 & $17.7 \%$ & \\
\hline & & Above 55 years & 109 & $18.2 \%$ & 118 & $19.7 \%$ & \\
\hline \multirow{4}{*}{3} & \multirow{4}{*}{$\begin{array}{l}\text { Educational } \\
\text { Qualification }\end{array}$} & $\begin{array}{l}\text { Illiterate / Below } \\
10^{\text {th }} \mathrm{Std}\end{array}$ & 54 & $9.0 \%$ & 0 & $0.0 \%$ & \multirow{4}{*}{$\begin{array}{l}\chi^{2}=66.698 \\
\text { and } \\
p=0.000(S)\end{array}$} \\
\hline & & $\begin{array}{l}\text { SSC / } \\
\text { Intermediate }\end{array}$ & 44 & $7.3 \%$ & 84 & $14.0 \%$ & \\
\hline & & Graduation & 357 & $59.5 \%$ & 368 & $61.3 \%$ & \\
\hline & & $\begin{array}{l}\text { Post-Graduation } \\
\& \text { above }\end{array}$ & 145 & $24.2 \%$ & 148 & $24.7 \%$ & \\
\hline \multirow{4}{*}{4} & \multirow{4}{*}{ Annual Income } & Below 1 Lakh & 42 & $7.0 \%$ & 42 & $2.0 \%$ & \multirow{4}{*}{$\begin{array}{l}\chi^{2}=23.541 \\
\text { and } p=0.085 \\
(\mathrm{NS})\end{array}$} \\
\hline & & 1-3 lakhs & 202 & $33.7 \%$ & 202 & $17.0 \%$ & \\
\hline & & 3-5 lakhs & 244 & $40.7 \%$ & 244 & $46.0 \%$ & \\
\hline & & 5-10 lakhs & 112 & $18.7 \%$ & 112 & $35.0 \%$ & \\
\hline \multirow{5}{*}{5} & \multirow{5}{*}{ Occupation } & $\begin{array}{l}\text { Government } \\
\text { Employee }\end{array}$ & 278 & $46.3 \%$ & 24 & $4.0 \%$ & \multirow{5}{*}{$\begin{array}{l}\chi^{2}=604.407 \\
\text { and } \\
\mathrm{p}=0.000(\mathrm{~S})\end{array}$} \\
\hline & & Private Employee & 18 & $3.0 \%$ & 322 & $53.7 \%$ & \\
\hline & & $\begin{array}{l}\text { Business/Corpora } \\
\text { tes }\end{array}$ & 81 & $13.5 \%$ & 77 & $12.8 \%$ & \\
\hline & & $\begin{array}{l}\text { Students/Unempl } \\
\text { oyed }\end{array}$ & 39 & $6.5 \%$ & 125 & $20.8 \%$ & \\
\hline & & $\begin{array}{l}\text { Pensioners/farmer } \\
\text { s/others }\end{array}$ & 184 & $30.7 \%$ & 52 & $8.7 \%$ & \\
\hline \multirow{5}{*}{6} & \multirow{5}{*}{$\begin{array}{l}\text { Frequency of } \\
\text { Bank visit }\end{array}$} & Very rare & 13 & $2.2 \%$ & 98 & $16.3 \%$ & \multirow{5}{*}{$\begin{array}{l}\chi^{2}=48.763 \\
\text { and } \\
\mathrm{p}=0.000(\mathrm{~S})\end{array}$} \\
\hline & & Occasionally & 71 & $11.8 \%$ & 137 & $22.8 \%$ & \\
\hline & & Once in a week & 38 & $6.3 \%$ & 47 & $7.8 \%$ & \\
\hline & & Twice in a month & 118 & $19.7 \%$ & 117 & $19.5 \%$ & \\
\hline & & Monthly once & 360 & $60.0 \%$ & 201 & $33.5 \%$ & \\
\hline \multirow{5}{*}{7} & \multirow{5}{*}{$\begin{array}{l}\text { Relationship } \\
\text { with bank in } \\
\text { years }\end{array}$} & Less than a year & 2 & $0.3 \%$ & 45 & $7.5 \%$ & \multirow{5}{*}{$\begin{array}{c}\chi^{2}=132.054 \\
\text { and } \\
\mathrm{p}=0.000(\mathrm{~S})\end{array}$} \\
\hline & & 1-2years & 76 & $12.7 \%$ & 80 & $13.3 \%$ & \\
\hline & & $2-4$ years & 150 & $25.0 \%$ & 148 & $24.7 \%$ & \\
\hline & & 4-8years & 272 & $45.3 \%$ & 210 & $35.0 \%$ & \\
\hline & & more than 8years & 100 & $16.7 \%$ & 117 & $19.5 \%$ & \\
\hline
\end{tabular}




\begin{tabular}{|c|c|c|c|c|c|c|c|}
\hline \multirow{5}{*}{8} & \multirow{5}{*}{$\begin{array}{l}\text { Reason for } \\
\text { visiting bank }\end{array}$} & $\begin{array}{l}\text { Balance Enquiry- } \\
\text { new } \mathrm{A} / \mathrm{c}\end{array}$ & 117 & $19.5 \%$ & 89 & $14.8 \%$ & \multirow{5}{*}{$\begin{array}{l}\chi^{2}=40.257 \\
\text { and } p=0.000 \\
(S)\end{array}$} \\
\hline & & $\begin{array}{l}\text { Cash } \\
\text { Deposit/with } \\
\text { drawl }\end{array}$ & 103 & $17.2 \%$ & 103 & $17.2 \%$ & \\
\hline & & $\begin{array}{l}\text { Complaints/queri } \\
\text { es }\end{array}$ & 109 & $18.2 \%$ & 108 & $18.0 \%$ & \\
\hline & & Locker & 161 & $26.8 \%$ & 104 & $17.3 \%$ & \\
\hline & & $\begin{array}{l}\text { Loan } \\
\text { Services/others }\end{array}$ & 62 & $10.3 \%$ & 112 & $18.7 \%$ & \\
\hline \multicolumn{3}{|c|}{ Total } & 1200 & 100.0 & 1200 & 100.0 & \\
\hline
\end{tabular}

Source: Primary data, where N=No. of Samples, NS= Not Significant, $\mathrm{S}=$ Significant. ${ }^{*} \mathrm{p}=0.05$ Level of Significance

\section{STATISTICAL ANALYSIS RESULTS}

Table 1 exhibits that the majority of banking activities, transactions are made by males $(64.2 \%$ and $70.7 \%$ ) compared to females (35.8\% and 29.3\%) in public and private sector banks. Most of the individuals belonged to the age groups of 25 to 40 years $(40.7 \%$ and $35.5 \%)$ in both the sectors. When it comes to the educational qualifications, most of the respondents are graduates $(59.5 \%$ and $61.3 \%)$ followed by the post graduates $(24.2 \%$ and $24.7 \%)$ in the different sectors. Maximum number of the respondents fall in 3 to 5 lakh income group (40.7\% and $46.0 \%$ ) consisting of government employees (46.3\%) are more in public banks and private employees $(53.7 \%)$ in private sector banks. After introducing digital banking services, the respondents are visiting banks most probably once in a month than earlier days, having relation with the bank is nearly 4-8 years (45.3\% and 35.0\%) and visiting banks for different reasons in public and private sector banks. The associations of the demographic and banking parameters such as Gender $\left(\lambda^{2}=5.770\right.$ and $p$-value $\left.=0.016\right)$, Age $\left(\lambda^{2}=22.561\right.$ and $p$-value $\left.=0.000\right)$, Educational Qualification $\left(\lambda^{2}=56.698\right.$ and $p$-value $\left.=0.000\right)$, Occupation $\left(\lambda^{2}=604.407\right.$ and $p$-value $\left.=0.000\right)$, frequency of bank visit $\left(\lambda^{2}=48.763\right.$ and $p$-value $\left.=0.000\right)$, relationship in terms of years $\left(\lambda^{2}=132.054\right.$ and $\mathrm{p}$-value $=0.000)$ and reason for bank visit $\left(\lambda^{2}=40.257\right.$ and $\mathrm{p}$-value $\left.=0.000\right)$ among Type of banks (Public and Private) are mostly significant except the annual income of the respondents. The results were represented graphically for a better understanding of demographical variables and banking parameters.
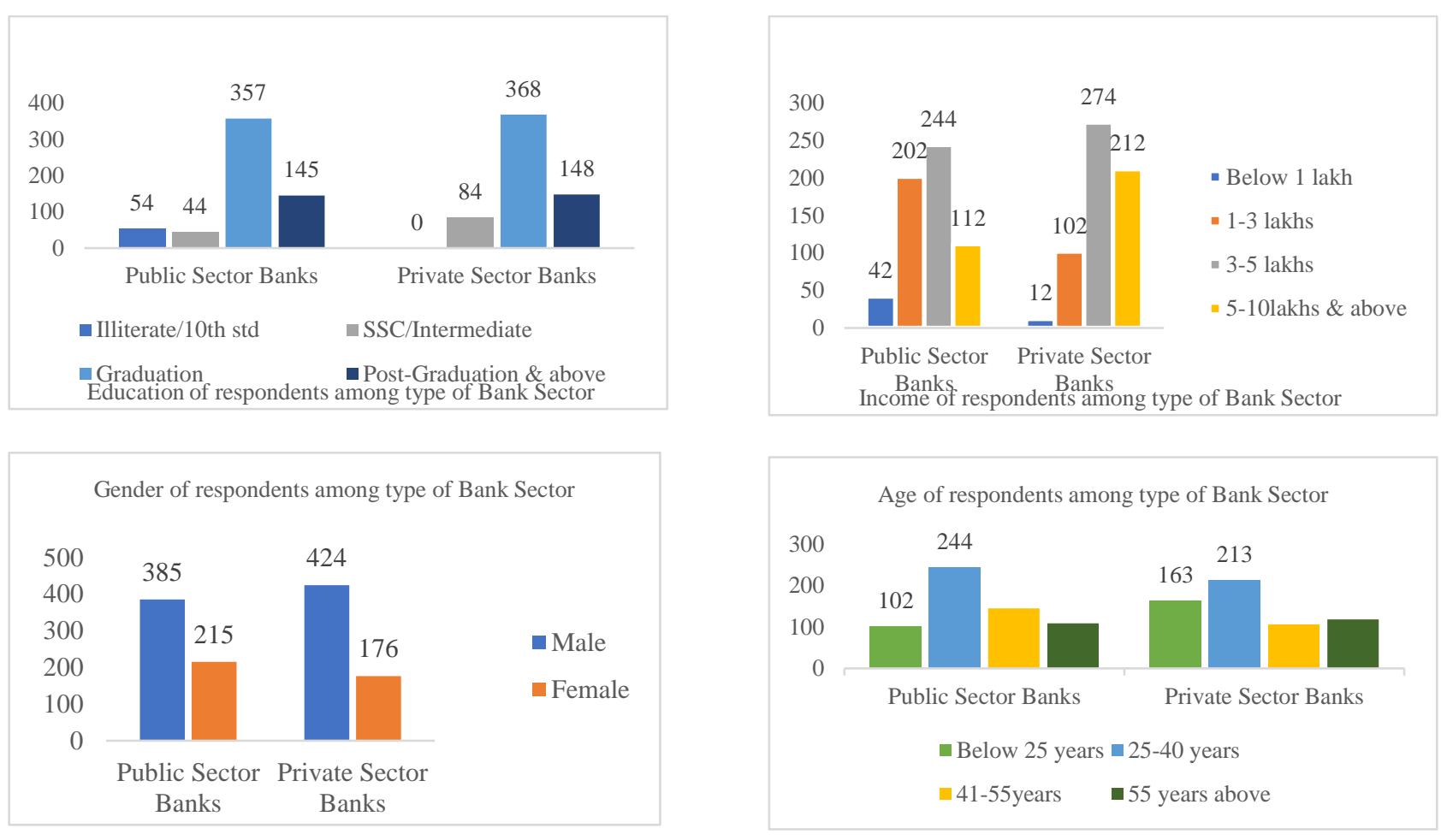


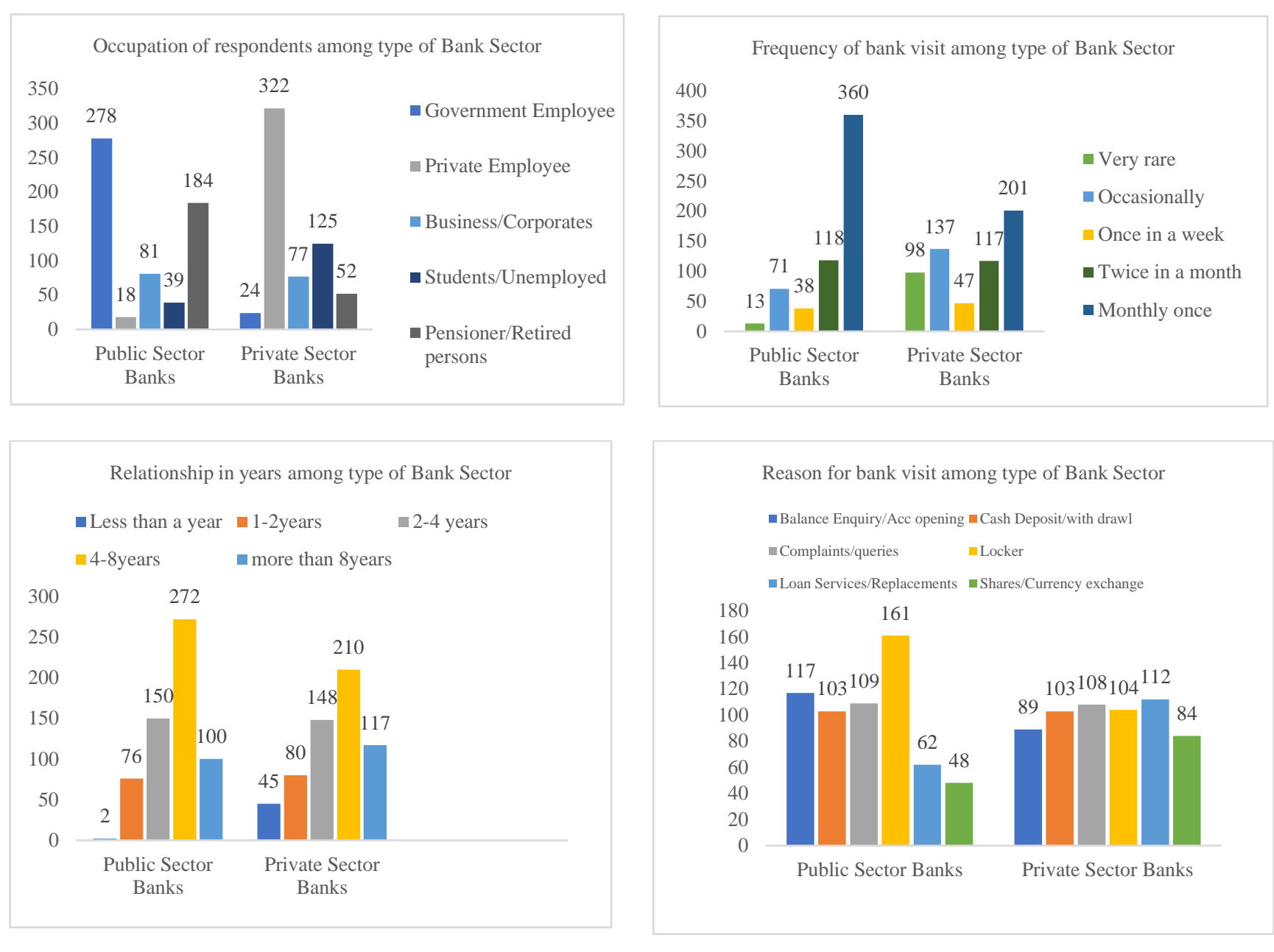

\section{Reliability Test for CRM parameters}

Table 2. Reliability Statistics for CRM Parameters

\begin{tabular}{|l|c|c|c|c|c|c|}
\hline $\begin{array}{l}\text { CRM } \\
\text { Parameters }\end{array}$ & $\begin{array}{c}\text { Customer } \\
\text { Service }\end{array}$ & $\begin{array}{c}\text { Customer } \\
\text { Knowledge }\end{array}$ & $\begin{array}{c}\text { Customer } \\
\text { Focus }\end{array}$ & $\begin{array}{c}\text { Customer } \\
\text { Orientation }\end{array}$ & $\begin{array}{c}\text { Customer } \\
\text { Satisfaction }\end{array}$ & $\begin{array}{c}\text { Customer } \\
\text { Loyalty }\end{array}$ \\
\hline $\begin{array}{l}\text { Cronbach's } \\
\text { Alpha }\end{array}$ & 0.830 & 0.859 & 0.864 & 0.811 & 0.844 & 0.717 \\
\hline
\end{tabular}

Source: Primary data

Table 2 depicts that reliability statistics for the CRM parameters, the Cronbach's values for the customer service parameter (0.830), customer knowledge value (0.859), customer focus (0.864), customer orientation (0.811), customer satisfaction (0.844) and customer loyalty (0.717). It exemplifies the internal consistency reliability of alpha is high in correlation between the items and the questionnaire is consistently reliable.

\section{Median Responses of CRM parameters}

Table 3. Median of CRM Parameters

\begin{tabular}{|l|c|c|c|c|c|c|}
\hline $\begin{array}{l}\text { CRM } \\
\text { Parameters }\end{array}$ & $\begin{array}{c}\text { Customer } \\
\text { Service }\end{array}$ & $\begin{array}{c}\text { Customer } \\
\text { Knowledge }\end{array}$ & $\begin{array}{c}\text { Customer } \\
\text { Focus }\end{array}$ & $\begin{array}{c}\text { Customer } \\
\text { Orientation }\end{array}$ & $\begin{array}{c}\text { Customer } \\
\text { Satisfaction }\end{array}$ & $\begin{array}{c}\text { Customer } \\
\text { Loyalty }\end{array}$ \\
\hline Median & 4.00 & 4.00 & 3.00 & 3.00 & 4.00 & 4.00 \\
\hline
\end{tabular}

Source: Primary data 
Table 3 revealed the median responses of CRM parameters to know the behavior of the customers. Most of the respondents were responded satisfactory opinion about the CRM parameters (Customer Service, Customer Knowledge, Customer Satisfaction and Customer Loyalty) which are employed in banking system. Further the respondents are given neutral opinion about the satisfaction levels on customer focus and customer orientation in implementing the practices in private and public banks in the region.

Mean rankings for CRM parameters

Table 4. Mean Ranks for CRM Parameters

\begin{tabular}{|l|l|l|l|l|l|l|}
\hline $\begin{array}{l}\text { CRM } \\
\text { Parameters }\end{array}$ & $\begin{array}{l}\text { Customer } \\
\text { Service }\end{array}$ & $\begin{array}{l}\text { Customer } \\
\text { Knowledge }\end{array}$ & $\begin{array}{l}\text { Customer } \\
\text { Focus }\end{array}$ & $\begin{array}{l}\text { Customer } \\
\text { Orientation }\end{array}$ & $\begin{array}{l}\text { Customer } \\
\text { Satisfaction }\end{array}$ & $\begin{array}{l}\text { Customer } \\
\text { Loyalty }\end{array}$ \\
\hline Mean Rank & 5.87 & 5.16 & 3.88 & 2.64 & 3.26 & 5.05 \\
\hline $\begin{array}{l}\text { Highest rank } \\
\text { construct }\end{array}$ & CS6 & CK6 & CF1 & CO1 & CSa3 & CL7 \\
\hline Mean Rank & 3.73 & 3.27 & 3.30 & 2.40 & 2.78 & 3.97 \\
\hline $\begin{array}{l}\text { Lowest rank } \\
\text { construct }\end{array}$ & CS5 & CK3 & CF3 & CO2 & CSa1 & CL6 \\
\hline
\end{tabular}

Source: Primary data

Table 4 depicts association among constructs through mean ranks for CRM parameters. For customer service among 8 items in the construct, highest mean rank is positioned for CS6 item i.e., banks have high integrity and security and the least rank goes to CS5 item is about goodwill. Followed by customer knowledge, maximum rank item in the construct is ranked for CK6 and the minimum is for CK3, next parameter is the customer focus which is for CF1 and low is CF3, for customer orientation high rank goes to the item $\mathrm{CO} 1$ and least is $\mathrm{CO} 2$, for the customer satisfaction construct the high order mean rank is for CSa3 and low is CSa1, Finally the last construct, customer loyalty's high rank goes to CL7 least observed in CL6.

\section{Factor Analysis}

Factor analysis is a data reduction technique or inter dependence techniques or data summarization technique examines the interrelationships among a large number of variables. The tool is used for finding the highly influenced variables among CRM parameters to employ in the banking sector (public and private).

Table 5. KMO and Bartlett's Test

\begin{tabular}{|l|l|r|}
\hline Kaiser-Meyer-Olkin Measure of Sampling Adequacy & 0.881 \\
\hline Bartlett's Test of & Approx. Chi-Square & 39036.533 \\
\cline { 2 - 3 } Sphericity & df & 703 \\
\cline { 2 - 3 } & Sig. & 0.000 \\
\hline
\end{tabular}

Source: Primary data

Extraction Method: Principal Component Analysis.

Table 5 elucidates measure of sample adequacy was computed through Kaiser-Meyer-Olkin (KMO) was 0.881 indicates that the samples are good enough for sampling. Also, the overall correlation matrices had been verified with Bartlett Test (approx. $\chi^{2}=39036.533$ and significant at $(\mathrm{p}=0.00<0.05)$ provided the validity of data. 
Table 6. Total Variance Explained

\begin{tabular}{|c|c|c|c|c|c|c|}
\hline \multirow{2}{*}{ Component } & \multicolumn{3}{|c|}{ Initial Eigenvalues } & \multicolumn{3}{|c|}{ Rotation Sums of Squared Loadings } \\
\cline { 2 - 7 } & Total & $\begin{array}{c}\text { \% of } \\
\text { Variance }\end{array}$ & $\begin{array}{c}\text { Cumulative } \\
\text { \% }\end{array}$ & Total & $\begin{array}{c}\text { \% of } \\
\text { Varianc } \\
\text { e }\end{array}$ & Cumulative \% \\
\hline 1 & 5.376 & 47.832 & 47.832 & 4.189 & 34.208 & 34.208 \\
\hline 2 & 2.751 & 18.026 & 65.858 & 2.616 & 29.264 & 63.472 \\
\hline 3 & 1.249 & 10.389 & 76.247 & 1.372 & 12.775 & 76.247 \\
\hline
\end{tabular}

Source: Primary data

Extraction Method: Principal Component Analysis.

The table 6 represents the variance percentage $(76 \%)$ of all factors resulting from the factor analysis over 38 factors were clustered into 3 factors which is determined as linear combinations of homogenous variables and most important parameters of customer relationship management practices in banks through principal component analysis.

Table 7. Factors influencing CRM Parameters

\begin{tabular}{|c|c|c|c|c|c|}
\hline Factors & CRM Parameters & $\begin{array}{c}\text { Factor } \\
\text { Loadings }\end{array}$ & $\begin{array}{l}\text { Eigen } \\
\text { values }\end{array}$ & $\begin{array}{c}\% \\
\text { Variance }\end{array}$ & $\begin{array}{c}\text { Cronbach's } \\
\text { Alpha }(\alpha)\end{array}$ \\
\hline $\begin{array}{l}\text { Focus } \\
\text { based } \\
\text { Customer } \\
\text { Service }\end{array}$ & $\begin{array}{l}\text { Services to individual customers } \\
\text { - CF1 } \\
\text { Beyond customer expectations - } \\
\text { CF2 } \\
\text { Treat the customers with great } \\
\text { care - CF3 } \\
\text { Strengthens emotional bonds - } \\
\text { CF4 } \\
\text { Uses customer suggestions - } \\
\text { CF5 } \\
\text { Interact with customers - CF6 } \\
\text { Customized web page - CS1 } \\
\text { Resolve complaints - CS2 } \\
\text { Follow up single customer - } \\
\text { CS3 } \\
\text { Flexible working hours - CS4 } \\
\text { Exercise goodwill deal with } \\
\text { customers - CS5 } \\
\text { High integrity and security - } \\
\text { CS6 } \\
\text { Speedy when counter services - } \\
\text { CS7 } \\
\text { Receptiveness-CS8 }\end{array}$ & $\begin{array}{l}0.508 \\
0.666 \\
0.662 \\
\\
0.828 \\
\\
0.487 \\
0.561 \\
0.720 \\
0.846 \\
\\
0.512 \\
0.737 \\
0.602 \\
\\
0.526 \\
0.726 \\
0.767 \\
\end{array}$ & 4.189 & 34.208 & 0.895 \\
\hline $\begin{array}{l}\text { Knowledge } \\
\text { based }\end{array}$ & $\begin{array}{l}\text { Access of Information - CK1 } \\
\text { Responsiveness - CK2 } \\
\text { Awareness on CRM } \\
\text { Programmes - CK3 } \\
\text { Reliability - CK4 } \\
\text { Communication - CK5 }\end{array}$ & $\begin{array}{l}0.663 \\
0.598 \\
0.504 \\
0.542 \\
0.537\end{array}$ & 2.616 & 29.264 & 0.846 \\
\hline
\end{tabular}




\begin{tabular}{|c|c|c|c|c|c|}
\hline Factors & CRM Parameters & $\begin{array}{c}\text { Factor } \\
\text { Loadings }\end{array}$ & $\begin{array}{l}\text { Eigen } \\
\text { values }\end{array}$ & $\begin{array}{c}\% \\
\text { Variance }\end{array}$ & $\begin{array}{c}\text { Cronbach's } \\
\text { Alpha }(\alpha)\end{array}$ \\
\hline $\begin{array}{l}\text { Customer } \\
\text { Orientation }\end{array}$ & $\begin{array}{l}\text { Trust - CK6 } \\
\text { Assurance - CK7 } \\
\text { Suitability using CRM } \\
\text { technology - CO1 } \\
\text { Relationship personnel - CO2 } \\
\text { Prior preference to customer - } \\
\text { CO3 } \\
\text { Customer touchpoints - CO4 }\end{array}$ & $\begin{array}{l}0.831 \\
0.769 \\
0.708 \\
0.720 \\
0.661 \\
0.517\end{array}$ & & & \\
\hline $\begin{array}{l}\text { Satisfaction } \\
\text { based } \\
\text { Customer } \\
\text { Loyalty }\end{array}$ & $\begin{array}{l}\text { Complaints management - CSa1 } \\
\text { Sincerity and helpfulness of } \\
\text { personnel - CSa2 } \\
\text { Opinion on services offered by } \\
\text { bank - CSa3 } \\
\text { Establish long term relationship } \\
\text { - CSa4 } \\
\text { Can meet customer expectations } \\
\text { - CSa5 } \\
\text { Changing the bank - CL1 } \\
\text { Considering loyal customer - } \\
\text { CL2 } \\
\text { Continuing services in future - } \\
\text { CL3 } \\
\text { Use other services offer by bank } \\
\text { - CL4 } \\
\text { Endorsing bank to others - CL5 } \\
\text { Switch to competitor banks - } \\
\text { CL6 } \\
\text { Trouble in provide service shift } \\
\text { bank - CL7 } \\
\text { First choice among other banks } \\
\text { area - CL8 }\end{array}$ & $\begin{array}{l}0.669 \\
0.617 \\
0.476 \\
0.698 \\
0.697 \\
0.857 \\
0.729 \\
0.798 \\
0.767 \\
0.768 \\
0.890 \\
0.896 \\
0.791\end{array}$ & 1.372 & 12.775 & 0.816 \\
\hline
\end{tabular}

Source: Primary data Extraction Method: Principal Component Analysis. Rotation - varimax method

Table 7 depicts that the first principal component accounted for $34.208 \%$ of variance with twelve statements as the "focus based customer service". The second principal component accounted for $63.472 \%$ of variance and was indicated in 11 statements as the "knowledge-based customer orientation". The third principal component accounted for $76.247 \%$ of variance indicated with 13 statements as "Satisfaction based customer loyalty". Overall observations from the factor analysis are that the respondents are very particular about focus based customer service, knowledge-based customer orientation, and satisfaction-based customer loyalty.

\section{DISCUSSION}

The study depicts some insights to the bank management to overcome the customer churn rate. The results of the study revealed the customer relationship management parameters influence on customer satisfaction and customer loyalty. It examines the significant association among the customer relationship management parameters towards the public and private sector banks of Chittoor district. The results enhance understanding regarding the CRM practices adopted by bank management and exploring the services offered by the respondents. 
It is revealed that Cronbach's alpha $(\alpha)$ for all the scale items in the construct for CRM parameters should be above ( $>0.50$ is better), above ( $>0.60$ is good) and, above ( $>0.70$ is acceptable) was mostly considered and accepted by the researchers (Nunnally, 1978) through reliability test for CRM parameters depicted in table 3. Perhaps can be explained through the median percentile observed for all six parameters approximately. It was found to be satisfactory for four variables such as customer service, customer knowledge, customer satisfaction and customer loyalty (CS, CK, CSa, and CL) except for two other variables, customer focus and customer orientation ( $\mathrm{CF}$ and $\mathrm{CO}$ ) was neutral in the opinion of customers neither satisfied nor dissatisfied with the practices implemented in the banks was displayed in table 4. The mean ranks test indicates the highest rank order to CS, CK and CL parameters and, lowest rank order $(\mathrm{CF}, \mathrm{CO}$, and $\mathrm{CSa}$ ) opted by the respondents to the items in the construct was illustrated in table 5 .

The study also employed factor analysis to know homogeneous (similar) CRM variables as factors and to test the relevance of various items in the constructs of CRM practices in banks of Chittoor district. Furthermore, to test the reliability, factor loading value (0.50) for item was considered (Hair et al. 1998). The study depicts the reliability was above 0.70 and the threshold value of Cronbach's alpha $(\alpha)$ is acceptable for the 3 extracted factors. Also, KMO of sample adequacy was performed for overall items was 0.881 and test of sphericity (Bartlett's) also significant at $\mathrm{p}>0.05$ indicates that employing factor analysis was good to further ensue. Principal component method (PCA) is used for extracting parameters with varimax rotation, to maximize the number of items with high factor loadings on a component, helps in justifiable factors in the construct (Malhotra, 2003). Eigen values $(=$ or $>1$ ) used to determine the extracted factors shown in table 9. A total of 38 items was extracted into 3 factors i.e., focus based customer service, knowledge-based customer orientation, satisfaction-based customer loyalty.

\section{CONCLUSION}

CRM solutions are no longer limited to just the retail banking rather, they are now essential for any entity that offering services. When it comes to banking system, it is essential to focus on implementing CRM practices and a great challenge to sustain and retain customers. Banking is now a customer-driven world that understand and serve the individual needs of their customers better, those will succeed. Adopting all CRM practices in banking system is much critical to serve customers at every point in the retaining process and building decent relationships to reduce loss of existing customers. Our study explored understanding regional behavioral changes of customers in implementing CRM practices of banks in Chittoor district. The study considered applicability of all practices to suit for the particular region in satisfying needs of the customers. The study identified the factors such as focus based customer service, knowledge-based customer orientation, satisfaction-based customer loyalty is playing vital role in implementing CRM practices of banking sector (public and private) in urban and semi-urban areas of Chittoor district. There is a need to give orientation among customers for enhancing their focus towards the products and digital services offered by the banks in the region. The awareness programs should be conducted for attaining the knowledge by utilizing the services properly in every aspect which leads to satisfaction in turn become loyal customer to banks. The study suggests that the applicability of CRM practices can be extended to rural area banks to satisfy the customer requirements. Thus, customer experience $(\mathrm{CX})$ and Customer engagement is also essential to compete effectively in today's banking system. Banks become more effective when it implements CRM practices, impeccably results in reducing customer attrition rate and increasing customer retention.

\section{Scope and Limitations of the Study}

- This study is limited to the extent that it covered the customers and employees of only 2 public sector banks and 2 private sector banks of Chittoor district of Andhra Pradesh.

- The study confined to urban and semi-urban area, excluded the rural areas in the districts of India. 


\section{REFERENCES}

Anabila, P., \& Awunyo-Vitor, D. (2013). Customer relationship management: A key to organizational survival and customer loyalty in Ghana's banking Industry. International Journal of Marketing Studies, 5(1), 107-117.

Al-Dmour, H. H., Algharabat, R. S., Khawaja, R., \& Al-Dmour, R. H. (2019). Investigating the impact of ECRM success factors on business performance. Asia Pacific Journal of Marketing and Logistics, 31(1), 1355-5855.

Bankole, O. A., Ogundipe, C. F., Enitilo, O., Ogundepo, Y. O., Oghogho, V. O., \& Eguabo, R. O (2020) Relationship Management and Customer Retention in the Banking Sector: A Case Study of Akure Metropolis, Nigeria. International Journal of Research in Social Science and Humanities $1(1), 21-28$

Dubey, N. K., \& Sangle, P. (2019). Customer perception of CRM implementation in banking context. Journal of Advances in Management Research, 16(1), 38-63. https://doi.org/10.1108/JAMR-122017-0118

Devendra, G. D. (2020). Current Scenario of Different Type of Services Marketing and Delivery in Customer Relationship Management. International Journal of Engineering and Management Research, 10(1), 30-32. https://doi.org/10.31033/ijemr.10.1.6

Hassani, H., Huang, X., Silva, E., \& Ghodsi, M. (2020). Deep Learning and Implementations in Banking. Annals of Data Science, 7(3), 433-446. https://doi.org/10.1007/s40745-020-00300-1

Hair, J., Anderson, R., Tatham, R., \& Black, W. (1998). Multivariate Data Analysis, 5th ed., PrenticeHall, Upper Saddle River, NJ.

Kirmaci, S. (2012). Customer relationship management and customer loyalty; a survey in the sector of banking. International Journal of Business and Social Science, 3(3).

Karahan, M., \& Kuzu, Ö. H. (2014). Evaluating of CRM in Banking Sector: A Case Study on Employees of Banks in Konya. Procedia-Social and Behavioral Sciences, 109, 6-10.

Khan, H. U., Lalitha, V. M., \& Omonaiye, J. F. (2017). Employees' perception as internal customers about online services: A case study of banking sector in Nigeria. International Journal of Business Innovation and Research, 13(2), 181-202.

Law, A. K., Ennew, C. T., \& Mitussis, D. (2013). Adoption of customer relationship management in the service sector and its impact on performance. Journal of Relationship Marketing, 12(4), 301330.

Mark, D. U., Grahame, R. D., \& Kathy, H. (2003). Customer loyalty and customer loyalty programs. Journal of Consumer Marketing, 20(4), 294-316.

Malhotra, N.K. (2003). Marketing Research- An Applied Orientation, Pearson Education, Singapore.

Nguyen, N., Leclerc, A., \& LeBlanc, G. (2013). The mediating role of customer trust on customer loyalty. Journal of Service Science and Management, 6(1), 96-109 http://dx.doi.org/10.4236/jssm.2013.61010 
Nunnally, J.C. (1978). Psychometric Theory, New York: McGraw-Hill.

Singh, D. (2013). Service quality and customer satisfaction: a comparative study of an Indian public VS private bank. Malaysian Management Journal, 17, 59-75.

Vugec, D. S., Spremić, M., \& Bach, M. P. (2017). IT governance adoption in banking and insurance sector: Longitudinal case study of cobit use. International Journal for Quality Research, 11(3), 691-716.

\section{Copyrights}

Copyright for this article is retained by the author(s), with first publication rights granted to the journal. This is an open-access article distributed under the terms and conditions of the Creative Commons Attribution license (http://creativecommons.org/licenses/by/4.0) 